\title{
Documentation of a Collection from the Poole Site (41TT47) in the Big Cypress Creek Basin in East Texas
}

Timothy K. Perttula

Heritage Research Center, Stephen F. Austin State University

Follow this and additional works at: https://scholarworks.sfasu.edu/ita

Part of the American Material Culture Commons, Archaeological Anthropology Commons, Environmental Studies Commons, Other American Studies Commons, Other Arts and Humanities Commons, Other History of Art, Architecture, and Archaeology Commons, and the United States History Commons

Tell us how this article helped you.

This Article is brought to you for free and open access by the Center for Regional Heritage Research at SFA ScholarWorks. It has been accepted for inclusion in Index of Texas Archaeology: Open Access Gray Literature from the Lone Star State by an authorized editor of SFA ScholarWorks. For more information, please contact cdsscholarworks@sfasu.edu. 
Documentation of a Collection from the Poole Site (41TT47) in the Big Cypress Creek Basin in East Texas

\section{Creative Commons License}

(c) (1) (8)

This work is licensed under a Creative Commons Attribution-NonCommercial 4.0 International License 


\title{
Documentation of a Collection from the Poole Site (41TT47) in the Big Cypress Creek Basin in East Texas
}

\author{
Timothy K. Perttula
}

\section{INTRODUCTION}

The Poole site (41TT47) is about 2.5 miles south of Mt. Pleasant, and is now situated within the Mount Pleasant Wastewater Treatment Plant. The site was originally recorded by Milton Bell and Ken Brown in 1971, who described it as "a thin scatter of artifacts, bone fragments, and charcoal flecks brought to surface on gopher hills" (Texas Historic Sites Atlas 2011). The site was estimated at ca. $50 \mathrm{x}$ $50 \mathrm{~m}$ in size; the artifacts "occurred mostly at the south side of the site. A metate was found in the center of the darker area. Wood charcoal flecks may be from more recent clearing" (Texas Historic Sites Atlas 2011). Their site map showed a $10 \times 12 \mathrm{~m}$ area with a dark organic staining, possibly evidence for a midden, or more recent burning activities. Bell and Brown suggested that the site may have a Late Caddo (ca. A.D. 1430-1680), Titus phase, occupation.

At the time the site was recorded in 1971, it appeared to be basically undisturbed, except for activities associated with the construction of a stock tank and its associated earthen berm just to the southeast of the Poole site. Thurmond (1990:82) subsequently examined a small collection of sherds from the Poole site, and described it as a "Late Caddoan limited use area." The Late Caddoan attribution of the site was based on one brushed body sherd and a Maydelle Incised jar rim.

In 1990, the Mount Pleasant Wastewater Treatment Plant was under construction on the northern end of the Poole site, across a fence line from a pasture where intact archeological deposits likely remained undisturbed. At that time, a small collection of artifacts was obtained from a private individual from the northern part of the Poole site before a lab building was fully constructed on the southern part of this tract of land. It is those artifacts that are the subject of this article.

According to Perttula and Nelson (1999), who conducted an archaeological survey of a part of the Poole site in 1999 because of proposed 1999 water and sewer system lines for the new City of Mount Pleasant municipal airport, it is a small prehistoric Titus phase settlement that dates from ca. A.D. 14301680. Although only a small portion of the site lay within the specific project area where the archaenlogical survey was conducted, like most Titus phase settlements, it may well contain trash middens, evidence for structures and other features, and a small family cemetery.

\section{SITE SETTING}

The site is situated on an upland ridge ( 310 feet amsl) overlooking the floodplain on the west side of Hart Creek, a southward-flowing tributary of Big Cypress Creek. The ridge is about 3-6 m above the flondplain.

\section{ARTIFACT ASSEMBLAGE}

The assemblage of artifacts in this documented collection includes 36 ceramic sherds, three lithic tools or tool fragments, three pieces of lithic debris, and one core. 


\section{Ceramic Sherds}

The ceramic sherds from the Poole site include 24 plain body and base sherds and 12 decorated rim and body sherds (Table 1). The plain/decorated sherd ratio is 2.0 . The sherds are primarily from grog-tempered vessels, as $86 \%$ have grog as the sole or principal temper. Almost $14 \%$ of the sherds have bone temper, either as the sole temper or in combination with crushed hematite; hematite is noted in only two sherd (5.6\%). One grog-tempered engraved body sherd is from a vessel made with a naturally sandy paste.

Table 1. Detailed sherd analysis, the Poole site (41TT47).

\begin{tabular}{|c|c|c|c|c|c|}
\hline Sherd Type & Temper & $\mathrm{FC}$ & ST & $\begin{array}{l}\text { Th } \\
(\mathrm{mm})\end{array}$ & Comments \\
\hline rim & grog & A & - & 7.2 & diagonal incised: direct rim and rounded lip \\
\hline rim & bonc-hem. & G & $\begin{array}{l}\mathrm{I} / \mathrm{E} \\
\mathrm{SM}\end{array}$ & 5.5 & $\begin{array}{l}\text { horizontal, vertical, and } \\
\text { diagonal engraved lines; } \\
\text { direct rim and flat lip }\end{array}$ \\
\hline body & grog & $\mathrm{E}$ & - & 9.3 & parallel pinched ridges \\
\hline body & grog & G & I SM & 8.0 & tool punctated row \\
\hline body & grog & B & - & 10.0 & fingernail punctated rows \\
\hline body & grog/SP & $\mathrm{G}$ & I SM & 9.1 & single straight engraved line \\
\hline body & grog & $\mathrm{F}$ & I SM & 5.1 & parallel engraved lines \\
\hline body & grog & $\mathrm{F}$ & - & 5.5 & plain \\
\hline body & grog-bone & B & $\begin{array}{l}\mathrm{I} / \mathrm{E} \\
\mathrm{SM}\end{array}$ & 6.5 & plain \\
\hline body & grog-hem. & $\mathrm{F}$ & - & 7.7 & plain \\
\hline body & grog & A & - & 6.7 & plain \\
\hline body & grog & $\mathrm{G}$ & - & 6.7 & plain \\
\hline body & grog & $\mathrm{H}$ & - & 6.4 & plain \\
\hline body & grog & G & $\begin{array}{l}\mathrm{I} / \mathrm{E} \\
\mathrm{SM}\end{array}$ & 7.8 & plain \\
\hline base & grog & G & E SM & 12.8 & plain \\
\hline
\end{tabular}

$\mathrm{FC}=$ firing conditions; $\mathrm{ST}=$ surface treatment; $\mathrm{Th}=$ thickness: $\mathrm{I}=$ interior; $\mathrm{E}=$ =xterior; $\mathrm{SM}=$ smoothed; $\mathrm{SP}=$ sandy paste:

$A=$ firing and cooled in an oxidizing environment; $B$-fired and cooled in a reducing environment: E=incompletely oxidized during firing; $\mathrm{F}-\mathrm{H}=$ fired in a reducing environment and cooled in the upen air 
The sherds are also from vessels that were fired in a varicty of ways. The majority (64\%), however, are from vessels that were fired in a reducing environment, but cooled in the open air (see Table 1), leaving a thin oxidized zone on either one or both sherd corc surfaces. The remainder of the sherds were fired in either an oxidizing or high oxygen environment (14.3\%), were fired and cooled in a reducing or low oxygen environment $(1+3 \%)$, or were incompletely oxidized during firing $(7.1 \%)$.

The vessels w'ere coil-made. beginning from a flat, thick $(12.8 \mathrm{~mm})$, disk base, then building the walls upwards to the rim. Rims range from 5.5-7.2 mm in thickness, while body walls range from $5.1-10.0 \mathrm{~mm}$. Decorated utility ware body sherds have a mean thickness of $9.1 \pm 0.73 \mathrm{~mm}$, suggesting utility ware vessels were larger in size and relatively durable. The mean thickness of fine ware engraved body sherds. by contrast, is $7.1 \pm 2.0 \mathrm{~mm}$. Fine wares apparently included both large and durable vessels as well as small and more delicate vessels.

Decorated fine ware sherds include two body sherds with a single straight line, one on the interior vessel surface (probably from a carinated bowl), two body sherds with parallel engraved lines (Figure le), and a rim sherd with horizontal, vertical, and diagonal engraved lines (Figure 1c). This sherd has some resemblances to Holly Fine Engraved (Suhm and Jelks 1962), although there is no visible excised triangle area on it; such a sherd suggests a pre-A.D. 1300 age, as Holly Fine Engraved vessels were made in East Texas up until ca. A.D. 1300 or thereabouts (Story 1990).

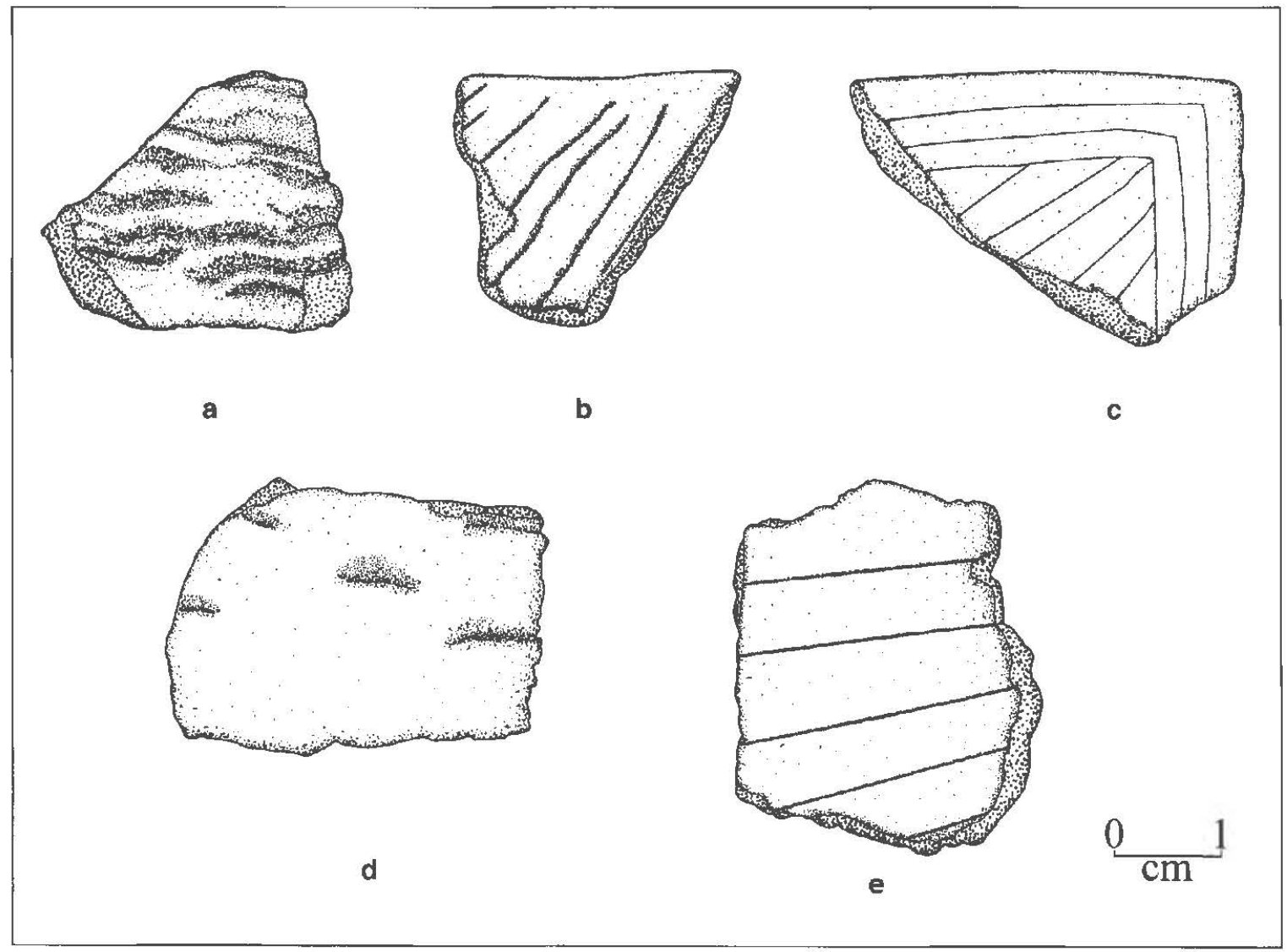

Figure 1. Decorated sherds from the Poole site (41TT47): a, pinched ridge body sherd; $b$, diagonal incised rim sherd; $\mathrm{c}$, horizontal, vertical, and diagonal engraved rim sherd; $d$, fingernail punctated body sherd; e, parallel engraved body sherd. Sherd drawings by Lance Trask. 
The decorated utility ware sherds $(n=7)$ are from vessels where the decoration was applied while the vessel was still wet, and had not been dried or fired. Utility ware vessels also tend to have coarse tempers, thick body walls, and would have been employed for cooking or storage purposes. Two sherds have incised decorations (see Figure 1b), one has an incised-punctated decoration, three are punctated (see Figure 1d), and one has parallel pinched ridges (see Figure la).

The incised rim has a series of diagonal incised lines on it (sce Figure 1b), and the lines would have extended around the entire vessel rim. The other incised sherd, a body sherd, has only a single straight incised line on it. One body sherd has opposed incised lines above a row of tool punctations; the punctations are likely at the rim-body juncture, although this is impossible to discern because of the small sherd size.

The pinched body sherd has closely-spaced parallel pinched ridges that cover the entire sherd surface (see Figure 1a). Given the apparent temporal context of the sherd, this may be from a Hollyknowe Pinched Ridged jar (cf. Webb and McKinney 1975).

Two of the sherd punctated body sherds have a single row of tool punctations, probably as a decorative element on the body of utility ware jars. The third punctated sherd has rows of widely spaced fingernail punctations (see Figure 1d) that would have covered much of the vessel body surface.

\section{Chipped and Ground Stone Tools}

Both chipped stone tools are flake tools. One is a unilateral gray chert flake tool with a $6.4+\mathrm{mm}$ use worn length, while the other is a gray novaculite side scraper (Figure 2). The scraper has a $26.0 \mathrm{~mm}$ use-worn length. Gray novaculite is also a non-local raw material that is available in Red River gravels or sources in the Ouachita Mountains of southeastern Oklahoma (Banks 1990).

The last tool is a small fragment, a resharpening flake, of a dark gray siliceous shale celt; this material is also from the Red River gravels and/or the Ouachita Mountains. These wood-working tools are part of the prehistoric Caddo stone tool tradition, so clearly celts were in use at the Poole site during the Caddo occupation.

\section{Lithic Debris}

Two of the three pieces of lithic debris are of quartzite, a locally available raw matcrial. Both are cortical pieces, indicating that stone tool manufacture - the reduction of pebbles to obtain flakcs usable for tools-occurred on the site. One of these picces came off a heat-treated pebble. The other piece of lithic debris is a non-cortical flake of gray chert. This material is non-local, with likely sources in the Red River gravcls well to the north of the site. This flake is probably indicative of the on-site resharpening of a completed tool.

In addition to the lithic debris, there is also a reddishbrown chert bipolar core in the collection. The core has $7+$ flake removals., and represents an attempt to reduce a small

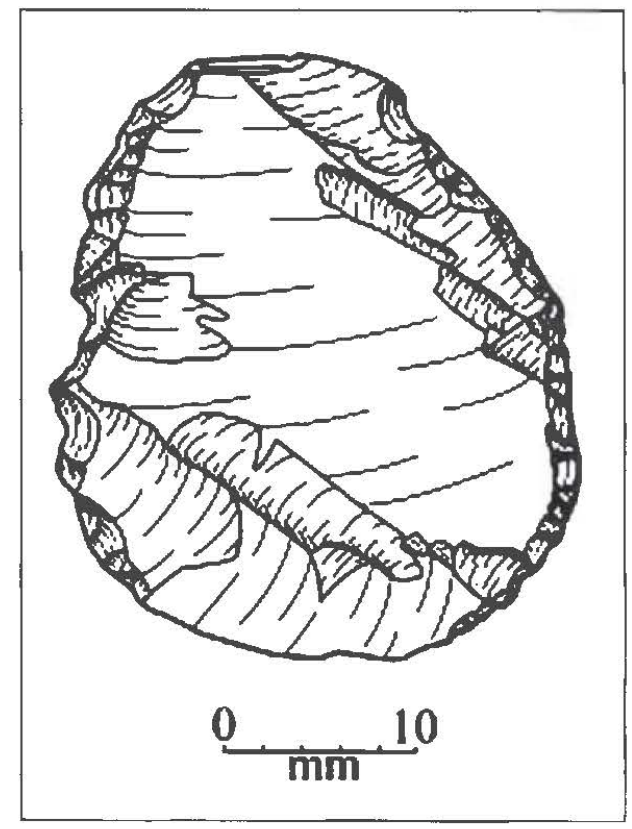

Figure 2. Novaculite side scraper from the Poole sitc (41TT47). chert pebble. 


\section{SUMMARY}

Although both Thurmond (1990) and Perttula and Nelson (1999:8) described the Poole site (41TT47) as having a Late Caddo, Titus phase component, no such evidence of the Titus phase occupation is apparent in this small documented collection from the site. Instead, the absence of brushed sherds in the sherd collection strongly suggests that the Caddo occupation on the part of the Poole site that was collected predates ca. A.D. 1250. After that time, brushed pottery dominates the utility wares being made and used by Caddo groups in the Big Cypress Creek basin, such that more than $50-60 \%$ of the decorated sherds on

Late Caddo sites in this area are brushed. The range of decorated sherds, including a considerable number of engraved fine wares $(41.7 \%$ of the decorated sherds) support a pre-A.D. 1250 temporal estimate.

The range of artifacts in this Poole site collection is indicative of what is commonly seen on a prehistoric Caddo domestic settlement in East Texas, where artifacts of daily live (i.e., ceramic vessels, chipped and ground stone tools, and the debris from tool manufacture and use) were in regular use, and then discarded in middens and trash areas after they were broken or no longer useful. As with almost all Caddo sites in the Big Cypress ('reek basin. the use of ceramic vessels for cooking, storage, holding liquids, and food service dominate the collection.

\section{ACKNOWLEDGEMENTS}

I appreciate the opportunity provided by Mr. Mark Thacker to study and document this collection from the Poole site. Lance Trask completed the artifact illustrations for this article.

\section{REFERENCES CITED}

Banks, L. D.

1990 From Mountain Peaks to Alligator Stomachs: A Review of Lithic Sources in the Trans-Mississippi South, the Southern Plains, and Adjacent Southwest. Memoir No. 4. Oklahoma Anthropological Society, Norman.

Perttula, T. K. and B. Nelson

1999 An Archeological Survey of 1999 Water and Sewer Systems for the City of Mount Pleasant New Municipal Airport, Titus County, Texus. Report of Investigations No. 34. Archeological \& Environmental Consultants, Austin.

Story, D. A.

2000 Introduction. In The George C. Davis Site, Cherokee County, Texas, by H. P. Newell and A. D. Krieger, pp. 1-31. 2nd Edition. Society for American Archaeology, Washington, D.C.

Suhm, D. A., and E. B. Jelks (editors)

1962 Handbook of Texas Archeology: Type Descriptions. Special Publication No. 1, Texas Archeological Society, and Bulletin No. 4, Texas Memorial Museum, Austin.

Texas Historic Sites Atlas

2011 41TT47. Accessed on the web, http://nueces.thc.state.tx.us, June 16, 2011.

Thurmond, J. P.

1990 Archeology of the Cypress Creek Drainage Basin, Northeastern Texas and Northwestern Louisiana. Studies in Archeology 5. Texas Archeological Research Laboratory, The University of Texas at Austin.

Webb, C. H., and R. R. McKinney

1975 Mounds Plantation (16CD12), Caddo Parish, Louisiana. Louisiana Archaeology 2:39-127. 